\title{
Online Robotics Course: Factors Affecting Students' Satisfaction toward e-Learning in Thailand
}

\author{
Wichian Premchaiswadi, Parham Porouhan \\ Graduate School of IT in Business \\ Siam University
}

\author{
Nucharee Premchaiswadi \\ Faculty of Information Technology \\ Dhurakij Pundit University
}

\begin{abstract}
Recently, "Robo Siam1" team from Siam University won The Best Creativity Awards in Robot@Home Championship 2011 and received the privilege of representing Thailand in the global-level “World RoboCup : Robot@Home 2012”contest in Mexico. seeking further success in the prospective robotics competitions, motivated the university to develop an optional robotics course (not core course) - for those sophomore students of Electrical and Computer Engineering, Mechanical Engineering and Computer Science programs - who voluntarily are interested to know more about robots and learning online. The course was designed based on the open source DARwIn-OP (Dynamic Anthropomorphic Robot with Intelligence - Open Platform). The winning team - and couple of sophisticated IT lectures - were appointed to design the syllabus and the course modules. Moreover, two lab sessions per week were dedicated to the design module of the course. From the theory (e-Learning) perspective, students learned how to setup, configure and program specific functions of a DARwIn-OP humanoid robot. In general, the course consisted of four main modules: (1) Motion, (2) Vision, (3) Hardware, and (4) Miscellaneous robotics topics. From the hardware perspective, students learned about the hardware components of a DARwIn-OP robot such as actuators, sensors, display and interfaces. Overall, the online course taught students on how to setup, configure and program specific functions of a DARwIn-OP humanoid robot. The objective of the paper is to identify the most significant factors affecting students' satisfaction toward the developed course. The findings show that "Self-efficacy" and "Perceived Usefulness" are the most important determinants of students' satisfaction.
\end{abstract}

\section{Introduction}

This paper describes a web-enhanced robotics course -developed at Siam University in Thailand - for those sophomore students who are curious and eager to learn more about robots and robotics competitions. The purpose of the research paper is to develop a comprehensive online course in robotics that encompasses various fields that are integral to robotic systems: Electrical and Computer Engineering, Mechanical Engineering and Computer Science programs preferably. Many students begin engineering or science study with no practical experience in robotics issues. Most have never even touched a robot, never built one, and written a computer program to control the robot. A wellstructured web-based robotics course was planned to aid in the development of practical skills, interest, and deep learning amongst Siam University students. The main challenge in the development of an online course in robotics was to effectively review the course organization in terms of content and complexity to make it acceptable and enjoyable to undergraduate students. In this paper we presented a robotics course for sophomore of Electrical and Computer Engineering, Mechanical Engineering and Computer Science programs at Siam University. Unlike many robotics courses offered in various academic institutions, this course combined classical robotics concepts such as robot manipulator kinematics, dynamics and control, with robot programming techniques. Students were able to watch the online tutorial videos, download the provided files and documents, and increase their $\mathrm{C}++$ programming skills and so on. Furthermore, at the end of every week, they had the chance to attend practical workshops developing the computer programs that control the robot and direct them to do the assigned online tasks.

The robotics course was designed and implemented based on the development of open source DARwIn-OP for the first time in May 2012 at Siam University. DARwIn-OP (Dynamic Anthropomorphic Robot with Intelligence - Open Platform) is an affordable, miniature-humanoid-robot platform with advance computational power, sophisticated sensors, high payload capacity, and dynamic motion ability to enable many exciting research, education, and outreach activities [1]. In fact, DARwIn-OP is a true open platform where undergraduate students are encouraged to modify it in both hardware and software in addition to various software implementations such as $\mathrm{C}++$, Python, LabVIEW, and MATLAB. 
Moreover, the university tried to build a new sort of interdisciplinary course while combining both engineering and practical standpoints all the way through using avant-garde technology. In other words, the objective of the course was to bring together the harmonizing dynamism of faculty teaching and research with the intention of establishing an exceptional learning atmosphere for incoming engineering sophomore students. The main goals of the course were to picture the students to a variety of programming issues altogether as providing them with basic applied robotics layout. Using this collective approach, at the same time, the university planned to grant the students the logic of engineering topics, while also giving them an experience of what the practice of robotics is similar to, all the way through practical knowledge and skills. The university anticipated that finally this movement would help the students to discover their favorite field of interest all the way through their studies and prospective career.

In this robotics course, the university moved much further than just using e-learning as a tool to teach obsolete robotics topics (as occurs in some other universities and high schools!). In contrary, Siam University aimed to use e-learning as an integrative theme and practical tool to teach up-todate issues about DARwIn-OP [2],[3]. Online tutorial videos and theoretical lectures, as well as practical lab sessions at the end of per week, let the university to use e-learning as a learning management system (as a helpful medium, in other words). By doing this, students learned about complicated DARwIn-OP devices and models, how to design, control and analyze them, and how to deal with online team work (group tasks and assignments) matters.

In general, this paper unfolded as follows. In section 2, we argued the characteristics of classic engineering curriculum with relevant robotics courses at other universities. In Section 3, we explained more detail in regard to the developed robotics course. The conceptual framework was described in Section 4. In Section 5, we described the outcomes of the course, as well as adjustments made all the way (because it was for the first time at Siam University that the course was taught), along with the student performance, course assessments, and feedbacks. Consequently, the paper wrapped up with conclusion and future study in Section 6.

\section{Background}

While undergraduate learning in robotics is rather common across the developed countries, few universities in Thailand currently offer specific robotics courses. By having a look at the usual university curriculum of Electrical and Computer
Engineering, Mechanical Engineering and Computer Science programs in Thailand, we realize that the first two years of these programs are generally designed for single-instructor mathematics and theory lecture courses, whereas lab-based courses are developed more for the third and fourth years. In this paper, the course that we expanded is far away from the mentioned strategy because it supports a teamteaching method by the faculty and team members of Graduate School of Information Technology for sophomore students of Electrical and Computer Engineering, Mechanical Engineering and Computer Science programs at Siam University. It worth to mention that, at present, Siam University, is Thailand's fifth oldest and largest private university offering various undergraduate and postgraduate programs both in Thai and English languages.

Comparable courses to the one that Siam University has expanded are normally roboticsdriven in a strict content and environment, often bounding learning to difficult programming, computational, arithmetic and mechanical engineering only, but our course covered a wide area of humanoid robotics subjects such as mechanics, software, hardware, electrical engineering and computer science practices [4]. The associated courses are also classically determined for those students who are ahead of sophomore year, and therefore cannot as efficiently deal with the problem of retention and choice of major amongst engineering students.

On the other side of the coin, existing preparatory undergraduate courses regularly use elementary robotics topics as the starting platform for practical robotics learning. LEGO robots [8] are frequently used for motivating creative decision making, risk/critical management and problem solving concerning with students. Opposite with humanoid robots [5],[6],[7], LEGO robots are only restricted to individual microcontrollers, including the Handy Board, which are usually unable to support more platforms. Therefore, LEGO robots are normally limited to operating in adapted environments only, make them deficient in the capacity for real-world robotics practices.

To deal with such boundaries, DARwIn-OP —as a sophisticated robot platform - was chosen for the robotics course. DARwIn-OP was developed at Virginia Tech's Robotics and Mechanisms Laboratory and it is also known as RoMeLa [12],[13],[15]. In other words, DARwIn-OP is one of the four products (OLLO, BIOLOID, DYNAMIXEL, DARwIn-OP) of ROBOTIS company [5],[6],[8]. DARwin-OP is built on a $1.6 \mathrm{GHz}$ Intel Atom Z530-based FitPC2i which boasts a 4GB SSD, 2GB of DDR2 RAM, 802.11n WiFi. Shipments of this 17.9-inch tall humanoid robot were sent to universities first at a price of $\$ 9,600$, and later run $\$ 12,000$ at full retail. As a 
result, robotics team decided that DARwIn-OP was completely suitable for robotics educational platforms due to the following reasons: (1) Open platform: source codes, mechanical information, firmware and schematics of DARwIn-OP are open for general use; (2) Easy maintenance: The MX-28 of DARwIn-OP only requires 1 type of actuator maintenance; (3) Expandability: A modular robot DARwIn-OP allows modifications as the developer's different ideas or adding new features.

By going forward into a more sophisticated platform, the robotics team in Graduate School of IT did not plan to let the undergraduate students concentrate on building simple and childish robots only. It would be better if they have wider programming skills about more complex humanoid robots like DARwIn-OP [16] instead. Therefore the team decided to add robotics lab sessions to the online web-enhanced classes as well.

\section{Course Structure}

\subsection{Software Aspect of DARwIn-OP}

The online course taught students on how to setup, configure and program specific functions of a DARwIn-OP humanoid robot. Students also gained experience on how to execute the components required for motion planning on an advanced multiple degree of freedom in robots (because the online course was based on a set of tools within DARwIn-OP's software). The students had access to simulated environments and real robots based on a hands-on experience - using motion planning with real robots. Overall, the web-enhanced robotics course consisted of the four modules: (1) Motion, (2) Vision, (3) Hardware, and (4) Miscellaneous. Each module consisted of several sub-modules. The functionality of each module was outlined based on a class-based object-oriented programming language; generic, singleton, static and interface (See Figure 1). Students learned about using the online generic classes, online singleton classes, online static classes, web-based tutorial interfaces and methods to program a robot to perform certain tasks. For example, online generic classes and generic methods enabled the students to apply, with a single method declaration, a set of related methods or, with a single class declaration, a set of related types, respectively. In this course, students learned the fundamentals of the DARwIn-OP framework. The framework consisted of several modules and sub-modules such as device communication module, motion module, walking module, sensing module, behavior module, vision module, and diagnostics module [17]. The framework was developed with $\mathrm{C}++$ programming language where the code is operating systemindependent. The operating system-independent aspect of the framework was essential so that the code could be ported to any existing or future computer operating system, including the newlydeveloped Robot Operating System (ROS). The students were assigned to simply write a behavioral code for DARwIn without the need to develop a separate framework set and send their assignment to their lecturer through their student WebPortal account.
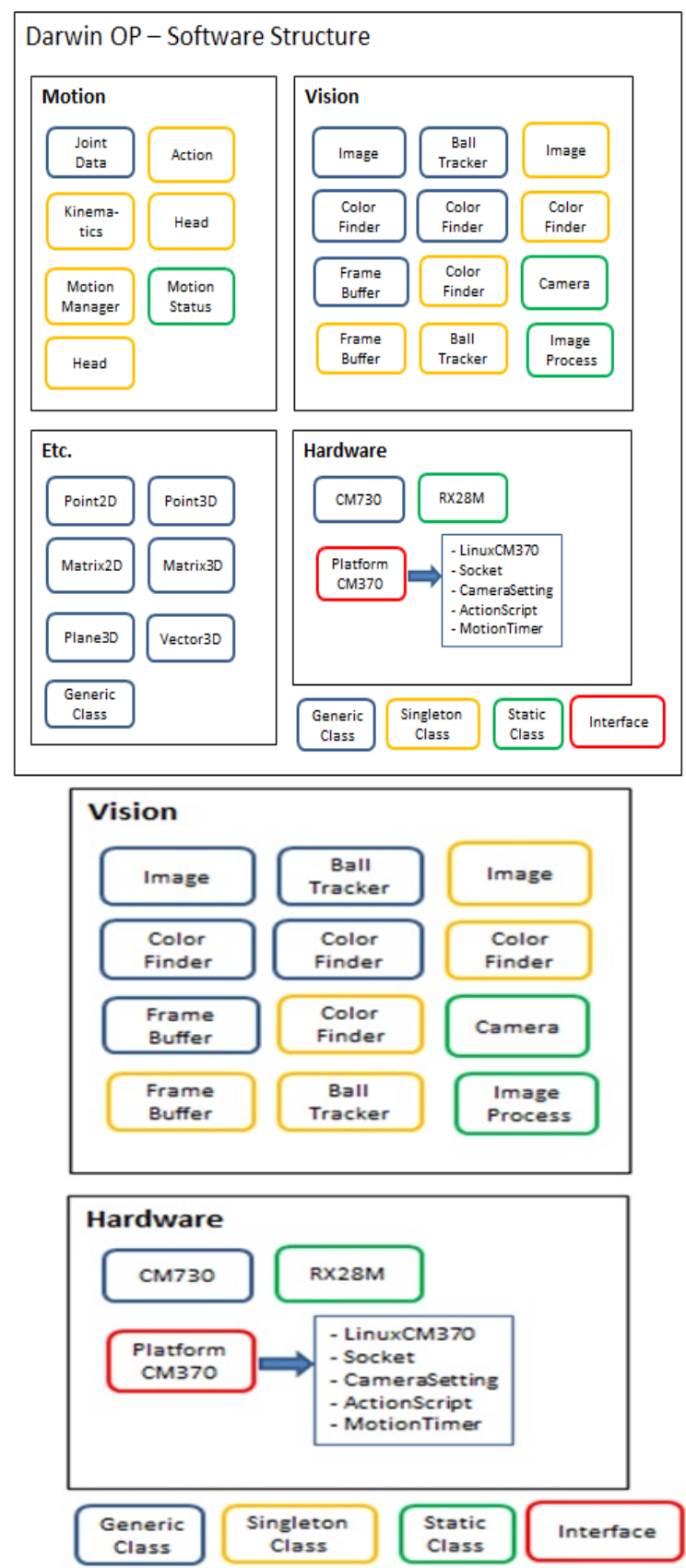

Figure 1. DARwIn OP Software Structure

\subsection{Hardware Aspect of DARwIn-OP}

In the robotics course, students learned the network based modular structure, the standard PC architecture of DARwIn-OP and the basic configuration of DARwIn-OP. They had to 
understand and use all devices such as actuators, sensors, LEDs, buttons, and external I/Os that were connected to the sub controller by a serial bus network. The modular network-based nature of the robot could help the students to modify any extremities by isolating the desired limb from the rest of the body with virtually no overall performance compromise of DARwIn-OP. Figure 2 shows the mechanical design of DARwIn-OP. DARwIn-OP has pluralities of sensors as illustrated in Figure 3 which maintains the scope of a networkbased modular structure. Basic sensors are a 3-axis gyroscope and a 3-axis accelerometer for posture estimation and balancing are mounted in the upper body.

A USB-based camera and a total of three microphones are located in the head. Optional sensors are force sensing registers (FSR) modules, in which four FSR's are placed in each foot, for ground reaction force measurements. Additional sensors also can be attached via external $\mathrm{I} / \mathrm{O}$ at the user's discretion. DARwIn-OP makes full use of the provided 3-axis accelerometer and gyroscope for balancing and posture estimation without compromising walking performance. In conjunction of proper implementation of closed-loop feedback control based on "immediate performance history", DARwIn-OP may be able to increase performance, such as faster walking or quicker recovery time after falling. Students also learned about the hardware components of a DARwIn-OP robot such as actuators, sensors, display and interfaces.

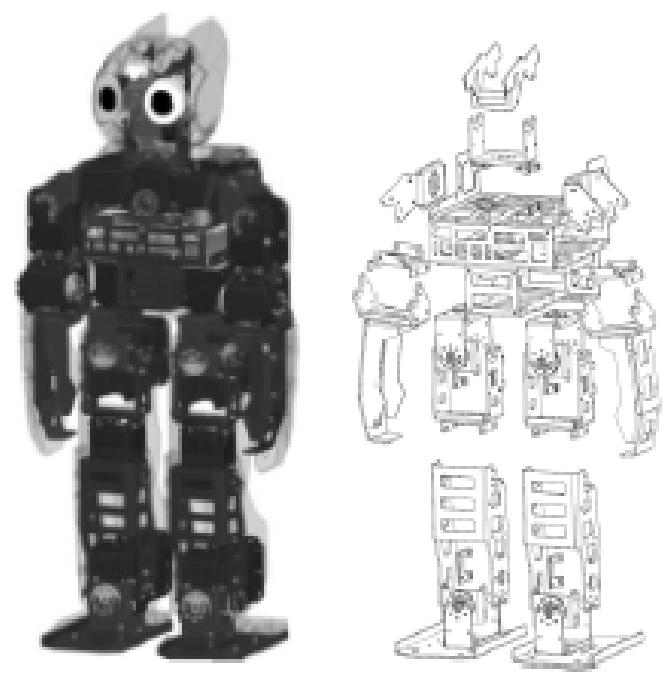

Figure 2. Mechanical design of DARwIn-OP

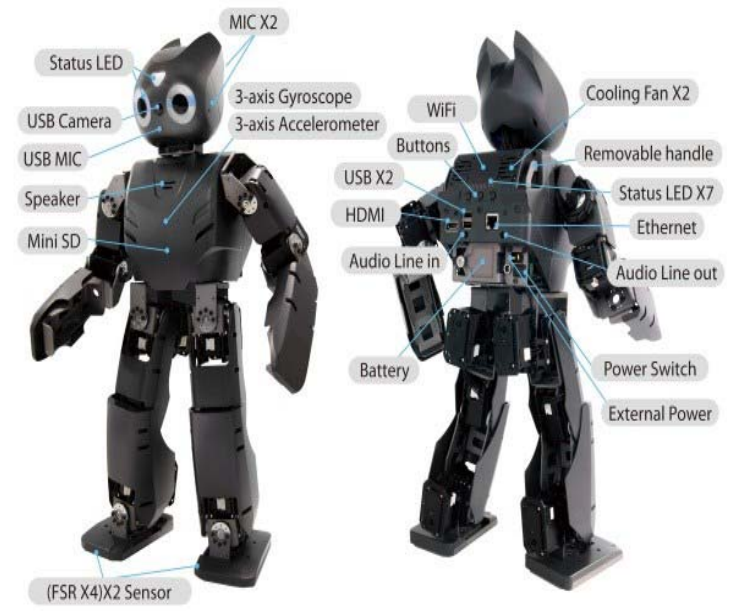

Figure 3. DARwIn-OP's Device Information.

In order to elaborate in hardware perspective of robotics learning (not only theory), the students were asked to complete a creative task in the lab. For example, they were asked to design the new improved MX-28 actuator for DARwIn-OP which has a higher resolution, faster communication speed, and more powerful controller compared to the previous RX-28. Students were encouraged to extend the usability of DARwIn-OP and its application domain. Some suggested projects for them included a mobile device (iPhone, Android, etc.) interface, modifications of the limbs of the robot, or additional sensor and actuator packages. Students extended these enhancements to a specific task, from novel human robot interaction experiences to new mobile manipulation endeavors.
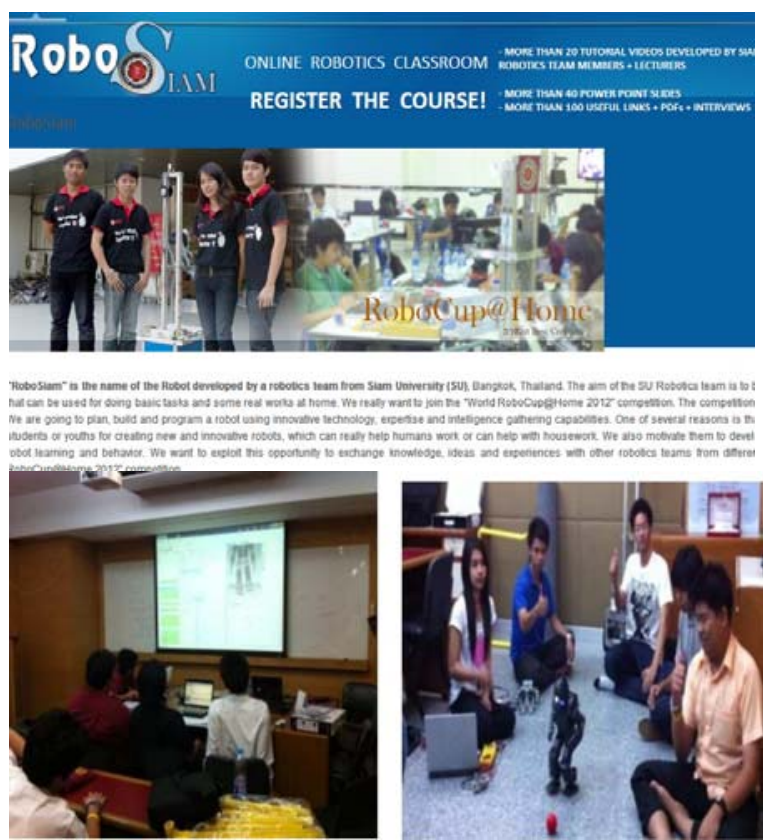

Figure 4. Students of Robotics Course at Siam University, Bangkok, Thailand. The course contained both the theory (web-based) and 
workshops (lab-based) classes. In addition to online tutorial videos and slides, students had the privilege to attend two lab sessions per week.

The online classes used a project-based learning environment at the end of each tutorial (video or power point slide) while focusing on problem solving skills amongst voluntarily registered students for the course. Students worked in teams toward the common goal of developing logical and creative solutions to problems using DARwIn-OP robotics technology (see Figure 4).

\section{Conceptual Framework}

"Social Cognitive Theory" —which is used in psychology, education, and communication - posits that portions of an individual's knowledge acquisition can be directly related to observing others within the context of social interactions, experiences, and outside media influences. On the other hand, "Flow Theory" also called "Optimal experience" is a concept explaining the state in which people are so involved in an activity that nothing else seems to matter; the experience itself is so enjoyable that people will do it even at great cost, for the sheer sake of doing it. Moreover, Unified theory of acceptance and use of technology (UTAUT) is a model which aims to explain user intentions to use an information system and subsequent usage behavior. The theory holds that four key constructs (performance expectancy, effort expectancy, social influence, and facilitating conditions) are direct determinants of usage intention and behavior.

We all knew that students' satisfaction concerning the web-based Robotics (DARwIn-OP) course could depend on a number of factors. The hypothesized model presented in Figure 5 has integrated variables from "Social Cognitive Theory", "Flow Theory" and "UTAUT ", in addition to the variables that were added in order to influence student satisfaction toward the developed robotics course at Siam University. In this study, satisfaction was defined based on the three main dimensions: course dimension (either web-based or lab-based), teaching assistant dimension (either web-based or lab-based), and student dimension (only student-based). Each dimension included its specific constructs.

All of the eight independent constructs [Quality of Course' Content \& Materials (with 5 questions), Quality of Course' Lab Sessions (with 3 questions), Diversity in Assessment (with 6 questions), Perceived Enjoyment (with 2 questions), Perceived Usefulness (with 4 questions), Quality of Teaching Assistants' Knowledge (with 4 questions), Teaching Assistants' Support \& Interaction (with 2 questions),
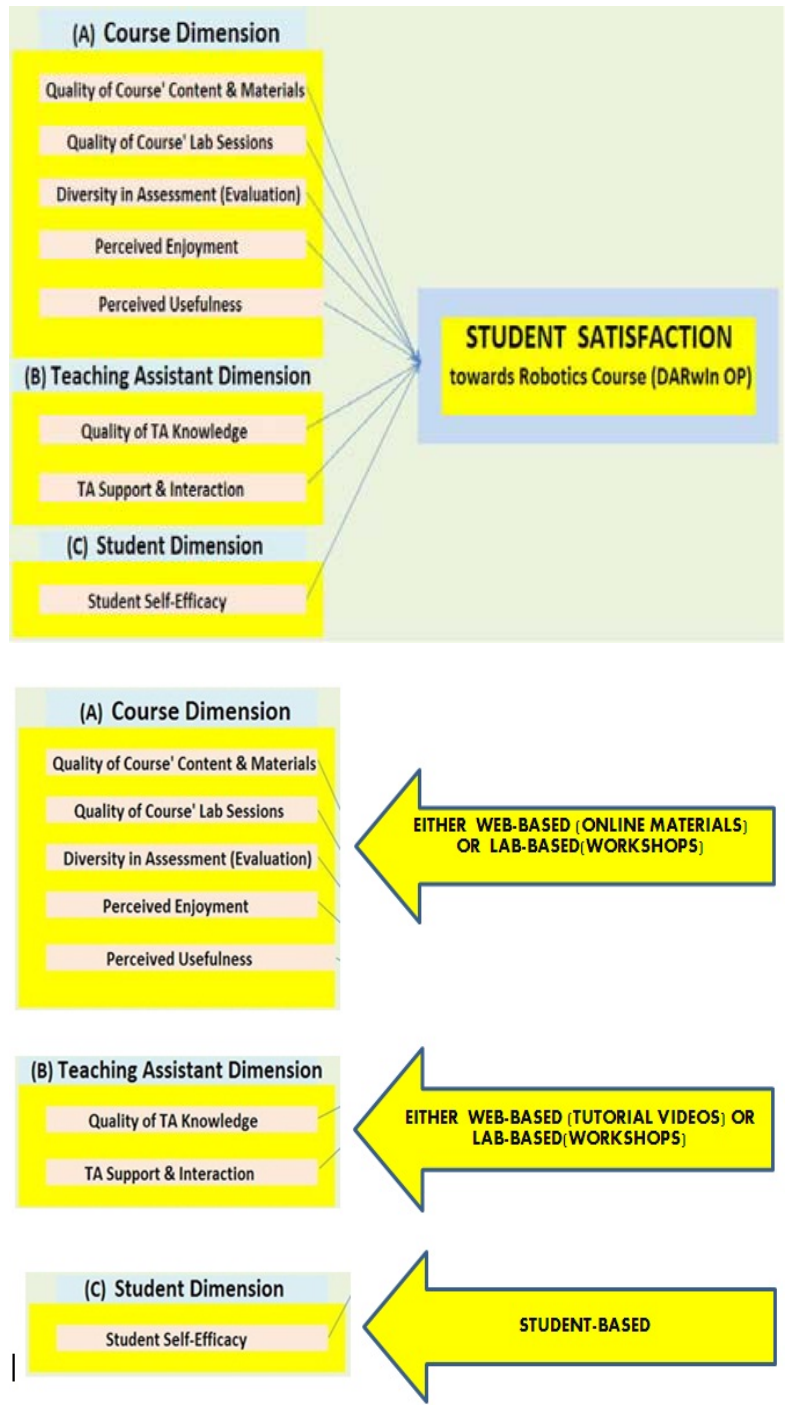

Figure 5. Initial Proposed Research Model.

$\begin{array}{cccc}\text { No. } & \text { Construct } & \text { Cronbach' Alpha } & \text { N of Items } \\ 1 & \text { Quality_Content } & 0.953 & 5 \\ 2 & \text { Quality_Lab } & 0.883 & 3 \\ 3 & \text { TA_Knowledge } & 0.812 & 4 \\ 4 & \text { TA_Support } & 0.831 & 2 \\ 5 & \text { Perceived_Useful } & 0.736 & 4 \\ 6 & \text { Self_Efficacy } & 0.814 & 4 \\ 7 & \text { Diversity_Assess } & 0.791 & 6 \\ 8 & \text { Perceived_Enjoy } & 0.822 & 2\end{array}$

Figure 6. Reliability Analysis for each Independent Variable.

and Students' Robotics \& Programming SelfEfficacy (with 4 questions)] besides the only dependent construct [Satisfaction of Students toward the Robotics Course (with 1 question)] in the proposed research model were adopted from existing 
literature and refined based on the specific topic of this study. The recommended minimum acceptable limit of reliability "alpha" for exploratory study is 0.60 . The results of $\alpha$-values for all the research constructs were above the recommended one (see Figure 6).

Data for this study was collected using a questionnaire distributed amongst those students who had enrolled in Robotics (DARwIn-OP) course at Siam University. Currently, Siam University is the fifth largest private university in Thailand.

In general, the study included 91 participants who completed the first trial launch of the robotics course (DARwIn-OP). Nevertheless, the second launch of the robotics course was paused due to some further assessment in terms of contents and structure of the course while making it ready for summer 2013. As mentioned earlier, all participants who registered to the course were sophomore students of Electrical and Computer Engineering, Mechanical Engineering and Computer Science programs at Siam University. The number of male students $(\mathrm{N}=51)$ was greater than the number of female students $(\mathrm{N}=40)$ whereas majority of their ages were between 20 and $29(\mathrm{~N}=78)$. An "online structured questionnaire" was used in order to collect the data about students' satisfaction -in the form of a survey. A five-point likert type was used in the questionnaire, and the overall Cronbach Alpha value of the questionnaire -for all the variables- was 0.703 in total (see Figure 7).

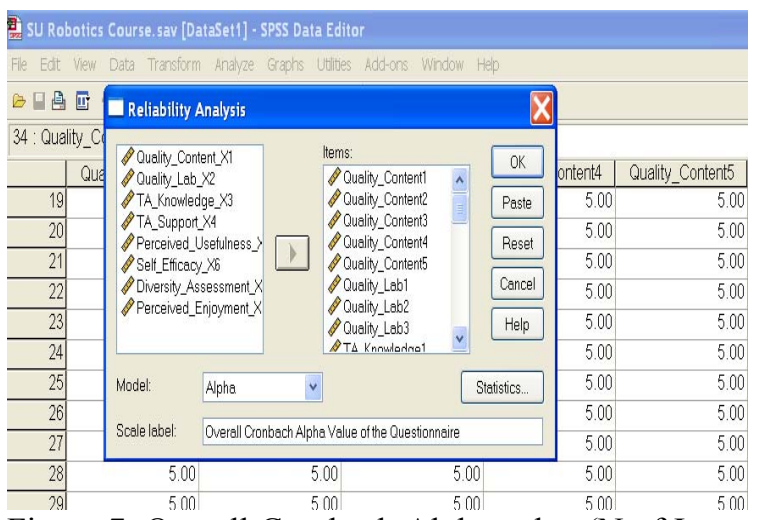

Figure 7. Overall Cronbach Alpha value ( $\mathrm{N}$ of Items 31)

In this study, descriptive statistics and correlation analysis were used. In multiple linear regression analysis, the relationship between the dependent variable, student satisfaction, and the following eight independent variables. Data was analyzed using SPSS 19.0 (Statistical Package for Social Sciences) software. We all know that, high discriminant validity provides evidence that a statistical construct is unique and captures some phenomenon that other measures do not. As shown in Figure 8, Pearson's Correlation coefficients indicated that two of the eight constructs were not supported in terms of validity. Therefore, after elimination of Perceived Enjoyment X4 and Diversity_Assess_X6, we had to provide a new conceptual framework (see Figures 9) including sox independent variables.

\begin{tabular}{|c|c|c|}
\hline Variables & Statistics & Student_Satisfaction_ \\
\hline \multirow[t]{3}{*}{$\begin{array}{l}\text { Student_Satisfaction_Y } \\
\text { _. }\end{array}$} & Pearson Correlation & 1 \\
\hline & Sig. (2-tailed) & \\
\hline & N & 86 \\
\hline \multirow[t]{3}{*}{ Quality_Content_X1 } & Pearson Correlation & $.231^{\star}$ \\
\hline & Sig. (2-tailed) & .032 \\
\hline & N & 86 \\
\hline \multirow[t]{3}{*}{ Quality_Lab_X2 } & Pearson Correlation & $.291^{\text {th }}$ \\
\hline & Sig. (2-tailed) & .007 \\
\hline & $\mathrm{N}$ & 86 \\
\hline \multirow[t]{3}{*}{ TA_Knowledge_X3 } & Pearson Correlation & $.442^{\text {t }}$ \\
\hline & Sig. (2-tailed) & .000 \\
\hline & N & 86 \\
\hline \multirow[t]{3}{*}{ Perceived_Enjoyment_X4 } & Pearson Correlation & .211 \\
\hline & Sig. (2-tailed) & .052 \\
\hline & N & 86 \\
\hline \multirow[t]{3}{*}{ TA_Support_X5 } & Pearson Correlation & $.460^{* \hbar}$ \\
\hline & Sig. (2-tailed) & .000 \\
\hline & $N$ & 86 \\
\hline \multirow[t]{3}{*}{ Diversity_Assess_X6 } & Pearson Correlation & -.076 \\
\hline & Sig. (2-tailed) & .486 \\
\hline & N & 86 \\
\hline \multirow[t]{3}{*}{ Self_Efficacy_X7 } & Pearson Correlation & $.475^{\text {th }}$ \\
\hline & Sig. (2-tailed) & .000 \\
\hline & N & 86 \\
\hline \multirow[t]{3}{*}{ Perceived_Usefulness_X8 } & Pearson Correlation & $-.543^{\text {th }}$ \\
\hline & Sig. (2-tailed) & .000 \\
\hline & N & 86 \\
\hline
\end{tabular}

${ }^{*}$. Correlation is significant at the 0.05 level (2-tailed).

${ }^{*}$. Correlation is significant at the 0.01 level (2-tailed).

Figure 8. Survey Item Cross-Correlations Table (2tailed Pearson).

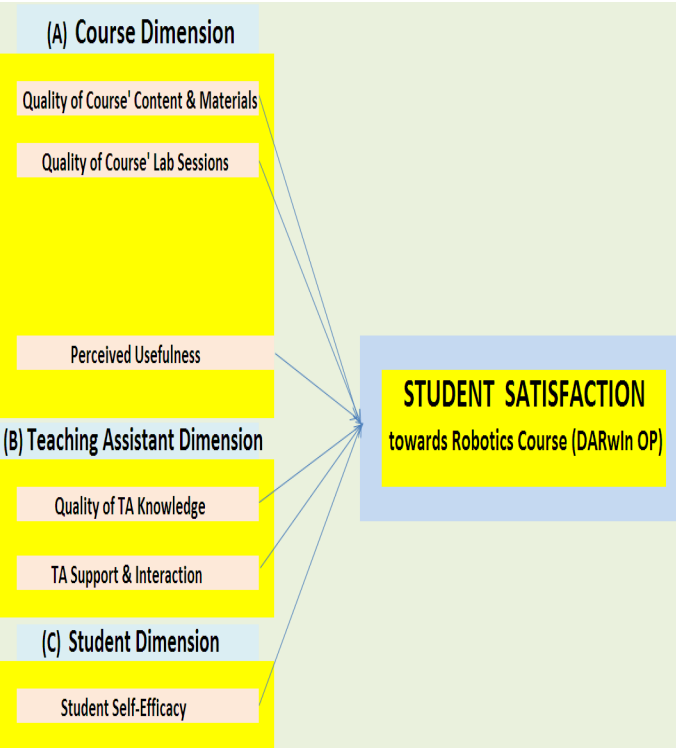




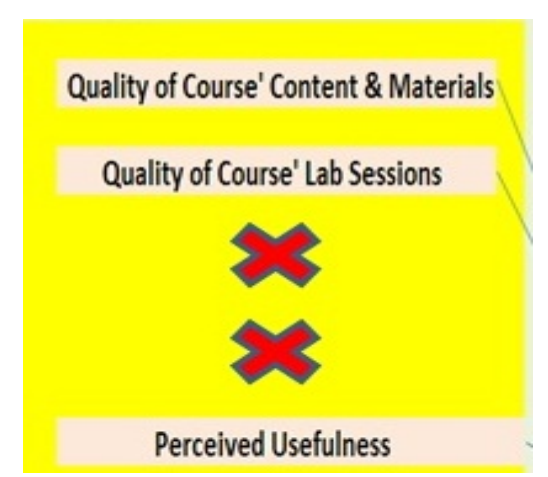

Figure 9. Final Proposed Research Model.

Considering the results of "Pearson Correlation", the hypotheses of the research were reduced to six as follows:

- H1: "Quality of Course' Content and Materials" (either web-based or lab-based) has a significant and positive effect on students' satisfaction toward the developed course.

- H2: "Quality of Course' Lab Sessions" (labbased) has a significant and positive effect on students' satisfaction.

- H3: "Perceived Usefulness" (either web-based or lab-based) has a significant and positive effect on students' satisfaction.

- H4: "Quality of Teaching Assistants Knowledge" (either web-based or lab-based) has a significant and positive effect on students' satisfaction.

- H5: "Teaching Assistants' Support and Interactivity" (either web-based or lab-based) has a significant and positive effect on students' satisfaction.

- H6: "Student' Self-Efficacy" (student-based only) has a significant and positive effect on students' satisfaction.

\section{Findings and Results}

The final grades for the first launch of the robotics course in May 2012 were computed by combining the web-based lecture (online submission of individual assignments and group tasks through Siam University's web portal) and lab grades (practical grades of workshops), which were weighted equally (see Figure12). In other words, the web-based lecture scores were based on the student performance on the mini-quizzes given at the end of each power point tutorial lecture session, and based on the group activities provided at the end of video tutorials. The lab grade consisted of student performance on the lab homeworks (pseudocode and conceptual questions), programming project assignments, and final project. The distribution of the students' final grades is shown in Figure 10.

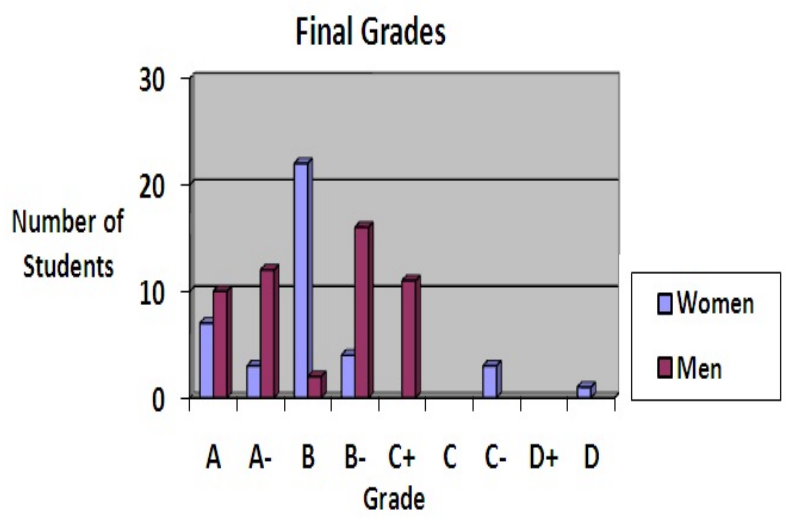

Figure 10. Distribution of Students' Final Grades.

Additionally, we used "Ridge Regression Analysis" to fit a predictive model to an observed data set of $\mathrm{y}$ and $\mathrm{X}$ values. By interpreting the results obtained from Ridge Regression Analysis, we were able to decide whether "Reject" or "Accept" the hypotheses of conceptual framework (see Figure 11). coeticlents"

\begin{tabular}{|c|c|c|c|c|c|}
\hline & \multicolumn{2}{|c|}{$\begin{array}{l}\text { Unstardardized } \\
\text { Coefficientis }\end{array}$} & \multirow{2}{*}{$\begin{array}{c}\text { Standardzed } \\
\text { Cooffcients } \\
\text { Beta }\end{array}$} & \multirow[b]{2}{*}{$\mathrm{t}$} & \multirow[b]{2}{*}{$\mathrm{Sg}$. } \\
\hline Model & $B$ & Sitd Error & & & \\
\hline (Constant) & .11 .457 & 1925 & & 5951 & 000 \\
\hline Qualihy_ContentXX & .175 & 263 & .047 & .663 & 509 \\
\hline Quallity__abl, $X 2$ & 1.004 & .188 & 314 & 5.338 & 000 \\
\hline TA_knowledge X3 & 1.154 & 230 & 345 & 5010 & 000 \\
\hline TA_Supoot X5 & 639 & .196 & .193 & 3258 & .002 \\
\hline Self_Efficay_XT & 1924 & 238 & .451 & 8085 & .000 \\
\hline $\begin{array}{l}\text { Perceived_Usefunness_ } \\
\times 8\end{array}$ & .734 & .106 & .418 & .6955 & .000 \\
\hline
\end{tabular}

8. Dependent Variable: intertion To _Lse_Y

Figure 11. Linear Regression Coefficients Results.

- As you can see, students' satisfaction toward the course was not affected by "Quality of Course' Content and Materials" (either web-based or labbased) because Sig $=0.509>0.05$, tvalue $=0.663<2.0$, thereby rejecting $\mathrm{H} 1$.

- Students' satisfaction toward the course was positively affected by "Quality of Lab Sessions" ( lab-based) because $\mathrm{Sig}=0.000<0.05$, tvalue $=5.338>2.0$, thereby supporting $\mathrm{H} 2$.

- Students' satisfaction toward the course was positively affected by "Teaching Assistants' Knowledge" (either web-based or lab-based) because $\mathrm{Sig}=0.000<0.05, \quad \mathrm{t}$-value $=5.010>2.0$, thereby supporting $\mathrm{H} 3$.

- Students' satisfaction toward the course was positively affected by "Teaching Assistants 
Support and Interactivity" (either web-based or lab-based) because $\mathrm{Sig}=0.002<0.05$, tvalue $=3.258>2.0$, thereby supporting $\mathrm{H} 4$.

- Students' satisfaction toward the course was very highly affected by "Students' SelfEfficacy" (student-based) because $\mathrm{Sig}=0.000<0.05, \quad \mathrm{t}$-value $=8.085>2.0, \quad$ thereby supporting $\mathrm{H} 5$.

- Students' satisfaction toward the course was highly affected by "Perceived Usefulness" (either web-based or lab-based) because $\mathrm{Sig}=0.000<0.05, \quad \mathrm{t}$-value $=6.955>2.0, \quad$ thereby supporting H6.

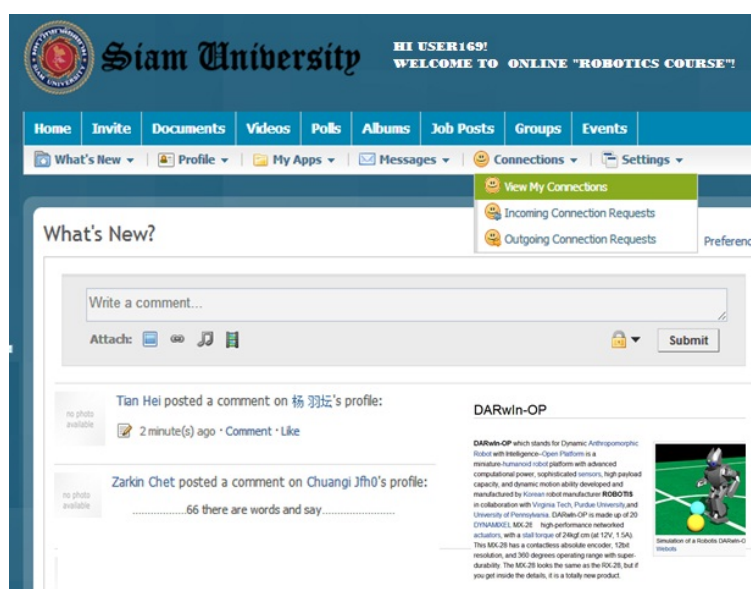

Figure 12. The final grades were computed by combining the online submission of the individual and group assignments through Siam University's Robotics Course web portal. Lab grades (workshops) were calculated separately based on the students ability in programming project assignments. Finally, both of the web-based and lab-based grades were weighted equally.

As a result, students" "self-efficacy" was recognized as the most significant factor affecting students' satisfaction toward the course. This was anticipated somehow! We knew that for majority of students, having a good background in both programming and robotics was the most important element in encouraging them to voluntarily register the optional (not core course) robotics course. However, "quality of course content and materials" (either web-based or lab-based) was not supported at all. Later, when we asked and interviewed the students - in more detail - about the problems of the course, they told us that they were not satisfied with quality of "power point" slides - and "PDF" complementary documents - embedded in the Siam University's Robotics Website at all. Similarly, they suggested us to add more useful "links" and "templates" (related to programming $\mathrm{C}++$ and
Kinetics of DARwIn-OP) to the contents of the robotics course. However, they were completely satisfied with the quality of video tutorials (recorded by IT lecturers and robotic team members). They said that the video tutorials were so straightforward and helpful. Similarly they were content with the extent of support, interaction and assistance that they received from robotics lecturers (either through webbased correspondences or through face-to-face lab sessions). Obviously, for these reasons, "Quality of Course' Content and Materials" option did not draw their attention.

Consequently, the most significant factors were sorted in Table 1.

Table 1. Most Significant Factors (Sorted).

\begin{tabular}{|c|c|c|c|}
\hline \multirow{2}{*}{ Priority } & \multicolumn{3}{|c|}{ The Most Significant Factors } \\
\cline { 2 - 4 } & Factor & $\boldsymbol{t}$-value & Sig. \\
\hline 1 & Self-Efficacy & 8.085 & 0.000 \\
\hline 2 & Perceived Usefulness & 6.955 & 0.000 \\
\hline 3 & Quality of Lab Sessions & 5.338 & 0.000 \\
\hline 4 & TA Knowledge & 5.010 & 0.000 \\
\hline 5 & TA Support & 3.258 & 0.002 \\
\hline
\end{tabular}

In addition, based on the ridge regression analysis findings, we formulated a model (function) for factors affecting the satisfaction of students toward online robotics course (DARwIn-OP) - at Siam University in Thailand - as follows:

\section{f(Satisfaction_Student_Y) =}

$-11.457+1.004$ Quality_Lab_X2 + 1.154 TA_Knowledge_X3 +0.639 TA_Support_X $\overline{5}+\overline{1} .924$ Self_Efficacy_X7 $-\overline{0} .734$ Perceived_Usefulness_X8

\section{Conclusion}

In this paper, we analyzed the most significant factors affecting satisfaction of sophomore students toward a web-based robotics course at Siam University in Thailand. The new course for the first time was launched in May 2012. Nighty-one sophomore - of Electrical and Computer Engineering, Mechanical Engineering and Computer Science programs - voluntarily registered the optional course (not core course).

The final grade assignments for the first launch of the course in May 2012 were computed by combining the web-based lecture (online submission of individual assignments and group tasks through Siam University's web portal) and lab grades (practical grades of workshops), which were weighted equally. From the theory (e-Learning) 
perspective, students learned how to setup, configure and program specific functions of a DARwIn-OP humanoid robot. In general, the course consisted of four main modules: (1) Motion, (2) Vision, (3) Hardware, and (4) Miscellaneous robotics topics. From the hardware perspective, students learned about the hardware components of a DARwIn-OP robot such as actuators, sensors, display and interfaces. Our findings show that "Self-efficacy" and "Perceived Usefulness" are the most important determinants of students' satisfaction in regard to the web-based robotics course.

\section{References}

[1] http://darwin-op.springnote.com/pages/6861909 K. Hirai, M. Hirose, Y. Haikawa, and T. Takenaka, "The Development of Honda Humanoid Robot", InternationalConference on Robotics and Automation, pp. 1321-1326, 1998.

[2] Choset, Howie. 16-311 Introduction to Robotics, Carnegie Mellon University, 2008. http://www.generalrobotics.org.

[3] Matarić, Maja. CSCI 445 Introduction to Robotics, University of Southern California, 2008. <http://wwwscf.usc.edu/ csci445.

[4] R. D. Beer, H. J. Chiel, and R. F. Drushel. Using autonomous robotics to teach science and engineering. Commun. ACM, 42(6):85-92, 1999.

[5] K. Kaneko, K. Harada, F. Kanehiro, G. Miyamori, and K. Akachi, "Humanoid robot HRP-3", International Conference on Intelligent Robots and Systems, pp. 247178, 2008.

[6] I.W. Park, J. Y. Kim, J. Lee, and J. H. Oh, "Mechanical Design of Humanoid Robot Platform KHR-3 (KAIST Humanoid Robot 3:HUBO)",International Conference on Humanoid Robots, pp. 321-326, 2005.

[7] S. Lohmeier, T. Buschmann, and H. Ulbrich, "Humanoid Robot LOLA",International Conference on Robotics and Automation, pp. 775-780, 2009.

[8] Martin, F.G. Circuits to Control: Learning Engineering by Designing LEGO Robots. Ph.D. Dissertation, Program in Media Arts and Sciences,Massachusetts Institute of Technology, 1994.

[9] Brian P. Gerkey, Richard T. Vaughan, and Andrew Howard, "The Player/Stage Project: Tools for Multi-Robot and Distributed Sensor Systems". In Proceedings of the International Conference on Advanced Robotics (ICAR), pages 317-323, Coimbra,Portugal, Jul 2003.

[10]ROBOTIS Co, Ltd. Web Site, http://support.robotis.com/en/product/dynamixel/dxl_com munication.htm" ROBOTIS Co, Ltd. Web Site.

[11]http://support.robotis.com/en/product/dynamixel/rx_se ries/rx-28.htm
[12]http://www.romela.org/main/DARwIn_OP:_Open_Pla tform_Humanoid_Robot_for_Research_and_Education.

[13]http://www.engadget.com/2010/12/17/open-sourcedarwin-op-bot-can-be-yours-for-just-12-000/(Open source DARwIn-OP).

[14]http://darwin-op.springnote.com/pages/6861909.

[15]http://robosavvy.com/RoboSavvyPages/Robotis/DAR wIn-OP/ paper581.pdf.

[16] Inyong Ha et al, Development of Open Humanoid Platform DARwIn-OP, SICE Annual Conference 2011, September 13-18, 2011, Waseda University, Tokyo, Japan.

[17]Allen, I.E., \& Seaman, J. (2007, October). Online nation: Five years of growth in online learning. Needham, MA: Sloan-C. Retrieved December 28, 2008, from http://www.sloanconsortium.org/publications/survey/pdf/o nline_nation.pdf

[18]American Distance Education Consortium (ADEC). (n.d.). Quality framework for online education. Lincoln, NE: Author. Retrieved December 28, 2008, from http:// www.adec.edu/earmyu/SLOANC41.htmlDistance Education 115.

[19]Astin, A.W. (1993). What matters in college? Four critical years revisited. San Francisco: Jossey-Bass. Baird, L.L. (1980). Importance of surveying student and faculty views. In L.L. Baird, R.T.

[20] Bender, D.M., Wood, B.J., \& Vredevoogd, J.D. (2004). Teaching time: Distance education versus classroom instruction. American Journal of Distance Education, 18(2), 103-114.

[21] Online Journal of Distance Learning Administration, 1(3). Retrieved January 1, 2009, from http://www.westga.edu/distance/Betts13.html

[22]Boettcher, J.V. (2004, June 29). Online course development: What does it cost? CampusTechnology. Retrieved August 28, 2008, from http://www.campustechnology.com/articles/39863

[23] Bolliger, D.U., \& Martindale, T. (2004). Key factors for determining student satisfaction in online courses. International Journal on E-Learning, 3(1), 61-67.

[24] Bower, B.L. (2001). Distance education: Facing the faculty challenge. Online Journal of Distance Learning Administration, 4(2). Retrieved January 1, 2009, from http://www.westga.edu/ distance/ojdla/summer42/bower4 2.html

[25]Carr, S. (2000, February 11). As distance education comes of age, the challenge is keeping the students. Chronicle of Higher Education, 46(23), A39A41.Cavanaugh, J. (2005). Teaching online - A time comparison. Online Journal of Distance Learning Administration, 8(1). Retrieved January 1, 2009, from http://www.westga.edu/distance/ojdla/spring81/cavanaugh 81.htm 
[26]Conceição, S.C.O. (2006). Faculty lived experiences in the online environment. Adult Education Quarterly, 57(1), $26-45$.

[27] Curran, C. (2008). Online learning and the university. In W.J. Bramble \& S. Panda (Eds.), (2000). Factors influencing.

[28] Faculty satisfaction with asynchronous teaching and learning in the SUNY learning network. Journal of Asynchronous Learning Networks, 4(3) 245-278. Retrieved August 28, 2008, from

http://www.sloan.org/publications/jaln/v4n3/v4n3_frederic ksen.asp

[29]Hislop, G. (2000). Working professionals as part-time on-line learners. Journal of Asynchronous Learning Networks, 4(2), 73-85. Retrieved September 18, 2007, from http://aln.org/publications/jaln/v4n2/v4n2_hislop.asp

[30] Liaw, S.-S. (2008). Investigating students' perceived satisfaction, behavioral intention, and effectiveness of elearning: A case study of the Blackboard system. Computers \& Education, 51(2), 864-873.

[31] Lin, Y., Lin, G., \& Laffey, J.M. (2008). Building a social and motivational framework for understanding satisfaction in online learning. Journal of Educational Computing Research, 38(1), 1-27.116 D.U. Bolliger and O. Wasilik Lock Haven University. (2004, December).

[32]Assessment plan for programs using distance education. Lock Haven, PA: Author. Retrieved January 1, 2009, from http://www.lhup.edu/planning-andassessment/assessment/assessmentplan/Distance\%20Educa tion $\% 20$ Assessment $\% 20$ Plan\%2012-03-04.doc

[33]Muilenburg, L.Y., \& Berge, Z.L. (2005). Student barriers to online learning: A factor analytic study. Distance Education, 26(1), 29-48.

[34] Yang, Y. \& Cornelius, L. F. (2004). Students' perceptions towards the quality of online education: A qualitative approach. Association for Educational Communications and Technology, 27, 861-877.

from http://www.nea.org/nr/nr000614.html

[35] Wang, Y. S. (2003). Assessment of learner satisfaction with asynchronous electronic learning systems. Information and Management, 41(1), 75-86.

[36] Ulmer, L.W., Watson, L.W., \& Derby, D. (2007). Perceptions of higher education faculty members on the value of distance education. The Quarterly Review of Distance Education, 8(1), 59-70.

[37] Lao, T. \& Gonzales, C. (2005). Understanding online learning through a qualitative description of professors' and students' experiences. Journal of Technology and Teacher Education, 133, 459-474.

[38] Levy, Y. (2003). A study of learners perceived value and satisfaction for implied effectiveness of online learning systems. Dissertation Abstracts International, 65(03), 1014A
[39] Sahin, I. (2007). Predicting student satisfaction in distance education and learning environments. Turkish Online Journal of Distance Education, 8(2), 1302-6488.

[40] Shea, P. J., Pickett, A. M., \& Pelz, W. E. (2003). A follow-up investigation of teaching presence in the SUNY learning network. Journal of Asynchronous Learning Networks, 7(2), 61-80.

[41] Tallent-Runnels, T., Lan, M. K., Fryer, W. Y., Thomas, J. A., Cooper, T. S. \& Wang, K., (2005). The relationship between problems with technology and graduate students' evaluations of online teaching. Internet and Higher Education, 8, 167-174.

[42] Young, A. \& Norgard, C. (2006). Assessing the quality of online courses from the students' perspective. Internet and Higher Education, 9, 107-115.

[43] Zeng, W. Y. \& Perris, K. (2004). Researching the efficacy of online learning: A collaborative effort amongst scholars in Asian open universities. Open Learning, 193, 247-264.

[44] Davies, J. \& Graff, M. (2005). Performance in elearning: online participation and student grades, British Journal of Educational Technology, 36(4), 657-664.

[45] Yukselturk, E., \& Yildirim, Z. (2008). Investigation of Interaction, Online Support, Course Structure and Flexibility as the Contributing Factors to Students' Satisfaction in an Online Certificate Program. Educational Technology \& Society, 11 (4), 51-65.

[46] Swan, K. (2001). Virtual interaction: Design factors affecting student satisfaction and perceived learning in asynchronous online courses. Distance Education, 22 (2), 306-331.

[47] Maki, R. H., Maki, W. S., Patterson, M., \& Whittaker, P. D. (2000). Evaluation of a Web-based introductory psychology course: I. Learning and satisfaction in on-line versus lecture course. Behavior Research Methods, Instruments, and Computers, 32 (2), 230-239.

[48] Roach, V., \& Lemasters, L. (2006), Satisfaction with online learning: A comparative descriptive study. Journal of Interactive Online Learning, 5 (3), 317-332.

[49] Sener, J. \& Humbert, J. (2003) Student satisfaction with online learning: an expanding universe. In J. Bourne \& J. C. Moore (Eds.), Elements of Quality Online Education: Practice and Direction, Needham, MA: Sloan Center for Online Education, 245-260.

[50] Inyong Ha, Yusuke Tamura, and Hajime Asama. (2011), Development of Open Humanoid Platform DARwIn-OP, SICE Annual Conference 2011, September 13-18, 2011, Waseda University, Tokyo, Japan.

[51] K. Hirai, M. Hirose, Y. Haikawa, and T. Takenaka, "The Development of Honda Humanoid Robot", International Conference on Robotics and Automation, pp. 1321-1326, 1998.

[52] K. Kaneko, K. Harada, F. Kanehiro, G. Miyamori, 
and K. Akachi, "Humanoid robot HRP-3", International Conference on Intelligent Robots and Systems, pp. 247178, 2008.

[53] I.W. Park, J. Y. Kim, J. Lee, and J. H. Oh, "Mechanical Design of Humanoid Robot Platform KHR-3 (KAIST Humanoid Robot - 3:HUBO)",International Conference on Humanoid Robots, pp. 321-326, 2005.

[54] S. Lohmeier, T. Buschmann, and H. Ulbrich, "Humanoid Robot LOLA",International Conference on Robotics and Automation, pp. 775-780, 2009.

[55] ROBOTIS Co, Ltd. Web Site, from

http://support.robotis.com/en/product/dynamixel/dxl_com muni cation.htm"

[56] ROBOTIS Co, Ltd. Web Site,

$\mathrm{http} / / /$ support.robotis.com/en/product/dynamixel/rx_series/ rx-2 8.htm

[57] Robin Mason and Martin Weller, Factors affecting students' satisfaction on a web course, Australian Journal of Educational Technology 2000, 16(2), 173-200. 